\title{
A mística do Ano Litúrgico: a teologia do domingo
}

\author{
Orientador: Luiz Fernando Ribeiro Santana \\ Mestrando: Rafael Neves de Oliveira \\ Área de Concentração: Teologia Sistemático-Pastoral \\ Linha de Pesquisa: Fé e Cultura
}

A teologia do domingo se desenvolve a partir da ressureição de Cristo. Diante desse evento, os Apóstolos compreenderam que esse dia deveria ser recordado como memorial pascal da nova e eterna Aliança. O domingo constitui, portanto, o novo tempo do culto cristão, deixando o sétimo dia, o sábado judaico, para então se tornar o primeiro dia da semana como o dia santo. O domingo também assume uma perspectiva escatológica, chamado de o oitavo dia, ou seja, o domingo que não tem fim e, para a vida da Igreja nascente, é um dia especial de culto. Os Padres da Igreja deixaram grande testemunho acerca desse dia que começa aqui para ter seu fim na eternidade. Essa dissertação propõe, então, perfazer um caminho de reflexão sobre a teologia do domingo, tendo em vista que, desde o Concílio Vaticano II, o domingo vem sendo celebrado com a proposta de uma participação plena, ativa e consciente. Para tanto, utilizou-se uma pesquisa qualitativa e bibliográfica, embasada na Sagrada Escritura, na Tradição, Magistério e Documentos da Igreja, assim como as leituras de vários estudiosos do assunto. A Constituição Sacrosanctum Concilium teve grande relevância no tocante à questão litúrgica na vida Igreja, ajudando a comunidade de fé a celebrar e viver o mistério de Cristo. A impostação da pesquisa é histórico-salvífica, visto que, desde a criação, já estava presente o desígnio do Pai de salvar e redimir o ser humano, e reúne elementos bíblicos e da eclesiologia litúrgica. O domingo torna-se o lugar privilegiado da irradiação da graça divina através da celebração do Mistério Pascal de Cristo, produzindo nos fiéis uma transformação para a vida. A comunidade que celebra a fé no dia do Senhor, se vê guiada pelo Espírito que estava presente na criação, verbalizado na aliança no Sinai e encarnado no Cristo.

Palavras-chave: Teologia litúrgica. Teologia do Shabat. Sagrada Escritura. 